\title{
Analisis Sentimen Pandemi Covid-19 Pada Streaming Twitter Dengan Text Mining Python
}

\author{
Anni Karimatul Fauziyyah ${ }^{1)}$, Deden Hardan Gautama ${ }^{2)}$ \\ 1, 2) Program Studi Informatika, Universitas Alma Ata \\ 1) anni.karim@almaata.ac.id, ${ }^{2)}$ hardan@almaata.ac.id
}

\begin{abstract}
The impact of the novel coronavirus (COVID-19) is widespread and will likely shape community behavior for months to come. And while the humanitarian and safety-related aspects of this outbreak are top of mind globally, it's unquestionable that social distancing, quarantining, and staying home will have a significant effect on media consumption, which could rise up to $60 \%$, according to recent research from Nielsen's U.S. media team. Social media, now a part of everyday life for most consumers engaged with the world digitally, became the primary source for buzz about all things COVID-19 as worries and news intensified. Sentiment analysis is applied in this study to analyze the opinions, feelings, and interests of individuals in the COVID-19. The purpose of this study is to analyze sentiment based on an opinion by classifying individual feelings such as sadness, happiness, or panic in facing a COVID-19 into sentiment level that is negative, positive or, neutral. In this paper, an open-source approach is presented where we have collected tweets from the Twitter API and then reprocessing, analyzing and, visualizing these tweets using python. Furthermore, Twitter data streaming will be processed and cleaned to parse data that can be classified based on opinion with a text mining algorithm using text blob Python. Feature extraction is done for the relationship between words by the Bigram and N-gram methods.
\end{abstract}

Keywords: Sentiment analysis, COVID-19, text mining, Bigram, Ngram

\section{PENDAHULUAN}

Di era semakin berkembangnya teknologi internet pada saat ini pertumbuhan jumlah data digital semakin besar. Media sosial adalah salah satu contoh penghasil data internet terbesar (Dhawan, 2014). Lebih dari jutaan orang atau organisasi menggunakan media sosial sebagai bentuk eksistensinya di dunia maya (Sivarajah, 2019). Menjalin hubungan sosial antar pengguna, berbagi informasi dan peristiwa akan menghasilkan data besar yang real time.

Seperti peristiwa pandemi COVID-19 atau virus corona yang merebak di seluruh dunia pada awal tahun 2020. Berdasarkan (JHU, 2020) pesebaran kasus COVID-19 di seluruh dunia pada 15 Maret 2020 sudah mencapai 1,986,986 kasus terkonfirmasi dan kasus meninggal mencapai 126,812. Sedangkan di Indonesia tercatat telah mencapai 4,839 kasus per 15 April 2020 dengan kasus meninggal 459 (BNPB, 2020). Dampak dari COVID-19 tersebar luas dan memungkinkan membentuk perilaku masyarakat selama masa pandemic belum berakhir. Sementara aspek-aspek yang terkait dengan kemanusiaan dan keselamatan dari pandemi ini menjadi perhatian utama secara global, dimana pembatasan jarak sosial, karantina, dan anjuran tinggal di rumah akan memiliki efek signifikan pada konsumsi media, yang bisa naik hingga 60\%, menurut penelitian terbaru dari tim media AS (Nielsen's U.S, 2020). Media sosial, sekarang menjadi bagian dari kehidupan sehari-hari bagi sebagian besar masyarakat yang terlibat dengan dunia secara digital, dan menjadi sumber utama untuk semua hal tentang COVID-19 ketika kekhawatiran dan berita semakin intensif. Akibat dari pandemi ini sejumlah negara di seluruh dunia memberlakukan lockdown dan pembatasan jarak social yang berimbas pada aktivitas masyarakat sehingga lebih aktif bersosialisasi di dunia maya dengan internet. 
Media sosial terutama twitter semakin menggaungkan peristiwa pandemi COVID-19 di jagad maya dengan munculnya hashtag tentang peristiwa pandemi COVID-19 hingga menjadi trending topik. Data yang dihasilkan twitter akan menjadi penting dan bermanfaat bagi masyarakat atau organisasi jika diolah dan di analisa. Salah satunya analisis sentimen twitter, merupakan metode untuk mengeksplorasi apakah konten yang dikumpulkan dalam keadaan positif, negatif atau netral (Luqyana, 2018). Analisis sentimen diterapkan pada penelitian ini untuk menganalisa opini, perasaan, pandangan, dan minat individu pada peristiwa pandemi COVID-19 dengan streaming data pengguna twitter yang membahas tentang topik COVID-19. Merebaknya pandemi ini diseluruh dunia dan berlakunya pembatasan interaksi sosial berpengaruh pada kondisi sosial masyarakat beredarnya isu-isu baik positif maupun negative bahkan timbul kepanikan besar di media social (Martin, 2020).

Berdasarkan uraian diatas, maka penulis akan menerapkan analisis sentimen berdasarkan dari opini dengan mengklasifikasikan perasaan individu seperti sedih, senang, atau panik menghadapi pandemic COVID-19 kedalam level sentimen yaitu negatif, positif atau netral. Tidak semua opini dapat digunakan sebagai analisa, sehingga harus dilakukan pemilahan, seperti pada penelitian (Setiowati, 2016) hanya opini positif dan negatif yang digunakan untuk menganalisa pengaruh opini di sosial media pada tingkat pelayanan hotel dan travel. Saat ini bahasa pemrograman untuk analisa data mining sangat berkembang. Pada penelitian (Saini, 2019) menggunakan pemrograman R untuk menganalisa sentimen data twitter. Sedangkan pada penelitian ini menggunakan python dengan library NLTK untuk artificial intelligence, yang lebih produktif daripada bahasa konvensional untuk pemecahan masalah yang melibatkan manipulasi string dan pencarian di library (Adawadkar, 2017).

Tujuan dari penelitian ini adalah melakukan collecting data twitter secara real time atau streaming yang diperlukan untuk analisa sentimen sesuai trend pandemi COVID-19. TwitterAPI digunakan untuk streaming data tweet dari Twitter dan menyimpan jumlah tweet secara real time. Selanjutnya data streaming twitter akan di processing dan cleaning untuk memilah data yang dapat diklasifikasikan berdasarkan opini dengan algoritma data mining dengan pemrograman python sehingga dapat dilakukan analisa dan visualisasi tweet ini menggunakan python. Ekstraksi fitur dilakukan untuk hubungan antara kata-kata dengan metode Bigram dan N-gram digunakan untuk analisis sentimen berdasarkan dari opini dengan mengklasifikasikan perasaan individu seperti sedih, senang, atau panik menghadapi pandemic COVID-19 kedalam level sentimen yaitu negatif, positif atau netral.

\section{TINJAUAN PUSTAKA}

\subsection{Text Mining}

Text mining dan data mining di persepsikan dalam keilmuan yang sama di karenakan algoritma sama dapat digunakan dalam kedua konsep mining tersebut (Eroglu, 2018). Namun, keduanya berbeda dalam arti bahwa data mining melibatkan data terstruktur, sementara teks berkaitan dengan fitur-fitur tertentu dan relatif tidak terstruktur dan memerlukan preprocessing. Text mining adalah bidang yang saling terkait dengan Natural Language Processing (NLP). Berikut proses utama Text mining berdasarkan (Yogapreethi, 2016):

- Ekstrasi Informasi

Langkah awal untuk menganalisis teks yang tidak terstruktur dengan menggali informasi. Proses pencarian dan hubungan antar frasa, untuk ukuran teks yang besar.

- Clustering

Memisahkan teks menjadi satu kelompok dan dengan cara memberi bobot untuk setiap kata. Daftar kelas dihasilkan dengan algoritma clustering untuk menghitung similarity. 
- Klasifikasi

Menemukan topik utama dokumen dengan menentukan meta data berupa label kelas untuk menganalisis dokumen.

- Visualisasi informasi

Menampilkan hasil mengekstraksi pola informasi, digunakan untuk interaksi pengguna dengan dokumen.

\subsection{Streaming Data Twitter}

Data twitter menjadi salah satu sumber data penelitian yang lama sering digunakan, (Cheng, 2013) menjelaskan mengapa Twitter digunakan sebagai sumber informasi: data dari berbagai sumber, melampirkan konten, komunikasi real time. Komponen tweet yang dapat digunakan untuk mengekstrak informasi:

- User name: identifikasi pengguna

- Time Stamp: waktu saat tweet itu dikirim

- Tweet Text: isi dari text tweet - harus kurang dari 140 karakter.

- Hashtags: symbol \#, tagar dikaitkan dengan topik tertentu.

- Replies: balasan pesan teks dari tweet

- Retweet : ketika pengguna membagikan tweet dengan pengikut mereka.

Untuk streaming data tweet dapat di akses dengan API REST Twitter yang memungkinkan untuk mengakses tweet semua orang. Tetapi API memiliki batasan hanya 6 sampai 9 hari terakhir akses tweet dan 18.000 tweet dalam satu panggilan. Pada python memiliki library untuk akses twitter salah satunya tweepy.

\subsection{Data Collection dan Cleaning di Python}

Data collection merupakan proses pengumpulan dan pengukuran informasi tentang variabel yang ditargetkan dengan cara sistematis. Pengumpulan data yang akurat sangat penting dalam menjaga integritas penelitian. Data cleaning proses identifikasi informasi yang tidak lengkap, atau tidak relevan dan kemudian memodifikasi atau menghapus data yang kotor (Saini, 2019).

\section{TextBlob}

Library python untuk memproses data tekstual. Menyediakan API yang konsisten untuk menganalisa ke dalam tugas-tugas pemrosesan bahasa alami (NLP) yang umum seperti part-of-speech tagging, ekstraksi kata benda, analisis sentimen (Praneeth, 2020). Skema library Textblob : Class textblob.blob.BaseBlob(text, tokenizer=None, pos_tagger=None, np_extractor=None, analyzer=None, parser=None, classifier $=$ None, clean_html=False)

Kelas dasar abstrak yang akan diwarisi oleh semua kelas textblob. Termasuk katakata, tag POS, NP, dan properti jumlah kata, termasuk metode dasar dunder dan string untuk membuat objek seperti string Python.

\subsection{Analisis Sentimen}

Langkah analisis sentimen dapat diterapkan sebagai berikut (Kiruthika, 2016):

- Level 1

Level kalimat: Mencari sentimen netral, negatif dan positif untuk setiap baris.

- Level 2

Level dokumen: menganalisa sentimen seluruh dokumen sebagai netral atau negatif atau positif .

- Level 3

Level aspek: Beberapa analisis sentimen menerapkan pengelompokan pada level ini di mana semua atribut yang memiliki hasil sentimen yang sama dikumpulkan. 
- Level 4

Level pengguna: memanfaatkan visualisasi data dari analisis sentiment untuk berinteraksi dengan pengguna social.

Dengan Python, metode Textblob.ngrams () mengembalikan daftar tupel kata-kata berurutan. Ini dapat digunakan untuk mendapatkan Unigrams (kata tunggal), Bigrams (dua kata) atau n-gram (beberapa kata berturut-turut).

Unigram: Textblob.ngrams $(\mathrm{n}=1)$ Bigram: Textblob.ngrams $(\mathrm{n}=2)$

N-gram: Textblob.ngrams ( $\mathrm{n}=3$ atau lebih).

\subsection{Pandemi COVID-19}

Pada 9 Januari 2020, CDC China melaporkan coronavirus baru sebagai agen penyebab wabah, yang masih satu jenis dengan SARS-CoV, disebut sebagai penyakit coronavirus baru 2019 (COVID-19). Pada 11 Maret 2020, 118.598 kasus COVID-19 dilaporkan di seluruh dunia oleh lebih dari 100 negara. Belum di temukan vaksin, mayoritas kasus (80\%) adalah infeksi saluran pernapasan dan pneumonia (ECDC, 2020). Tindakan preventif kesehatan masyarakat untuk mengurangi dampak pandemi salah satunya menjalankan aturan social distancing. Kecerdasan teknologi media sosial dimanfaatkan untuk meningkatkan untuk menjalani social distancing dengan media sosial berkaitan dengan situasi epidemic dapat digunakan sebagai sumber informasi untuk melakukan mobilisasi masyarakat mengikuti prosedur karantina, dengan mengurangi situasi panik dan ketakutan (Martin, 2020).

\section{METODE PENELITIAN}

Pada penelitian ini model penelitian yang di ajukan ditunjukkan pada Gambar. 1. Pada tahapan awal adalah proses streaming data API twitter, untuk mengakses diperlukan 4 key yaitu: consumer key, consumer secret key, access token key, access token secret key. Kata pencarian yang digunakan adalah variable \#coronavirus \#COVID-19 dengan pengaturan tweet bahasa inggris dan tanggal dari 6 april 2020. Pada penelitian ini akan di lakukan data collection 4000 tweet dari streaming twitter untuk menganalisis sentimen pengguna twitter dengan variabel pandemi COVID-19, coronavirus menggunakan python. Selanjutnya data collection disimpan ke database nosql mongodb.

Data collection yang disimpan di database dilakukan proses data cleaning sebelum data di analisa.

- filter:retweet $s$ : menghapus retweet yang mengandung konten duplikat,

- re.sub : menghapus url (tautan) menggunakan ekspresi reguler yang diakses dari kumpulan karakter yang ditentukan,

- set(lower_case):mengubah kata menjadi huruf kecil untuk menghilangkan kapitalisasi kata,

- nltk: menghapus stopword daftar kata yang kurang bermanfaat seperti who, you, is, am are

Proses extraksi fitur mencari kumpulan kata dari tweet yang telah melalui proses cleaning dimulai dengan menganalisa 100 kata teratas yang sering muncul pada tweet . collection.Counter:menampilkan kata-kata yang paling umum digunakan dan berapa kali digunakan. Selanjutnya dihitung nilai hubungan antar 100 kata teratas dengan bigrams: menghitung hubungan antar 2 kata.

Klasifikasi analisis sentiment menggunakan properti sentimen dari Textblob mengidentifikasi sikap dalam data teks tentang subjek yang menarik dalam bentuk Sentimen (polaritas, subjektivitas). Skor polaritas adalah float di kisaran -1.0 dan 1.0. Nilai lebih dekat ke 1 menunjukkan lebih banyak positif, sedangkan nilai lebih dekat ke -1 menunjukkan lebih banyak negatif. 


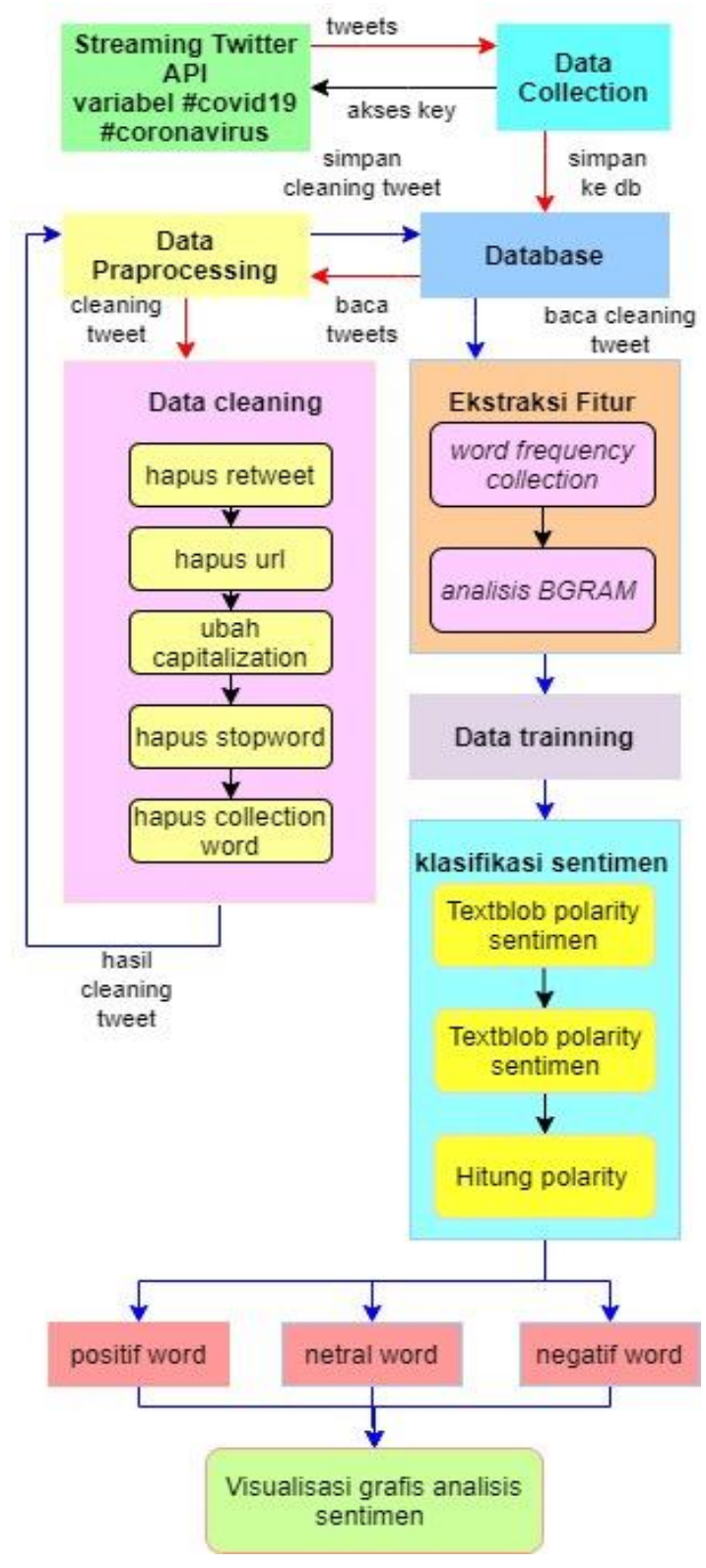

Gambar 1. Alur sistem analisis sentimen twitter python

\section{HASIL DAN PEMBAHASAN}

Hasil penelitian analisis sentimen terhadap streaming data twitter dengan python. Pada penelitian ini akan di lakukan data collection 4000 tweet dari streaming twitter untuk menganalisis sentimen pengguna twitter dengan variabel pandemi COVID-19, coronavirus menggunakan python. Kata pencarian yang digunakan adalah variable \#coronavirus \#COVID-19 dengan pengaturan tweet bahasa inggris dan data dari tanggal 6 april 2020. Selanjutnya data collection disimpan ke database nosql mongodb.

Pada Gambar 2 fungsi di python untuk collection data tweet dengan keyword pencarian: \#COVID-19, \#coronavirus, \#coronavirusoutbreak dan mengambil data user screen name dengan fungsi tweet .user.screen_name, untuk lokasi dengan fungsi tweet .user.location serta tweet text untuk status tweet . 


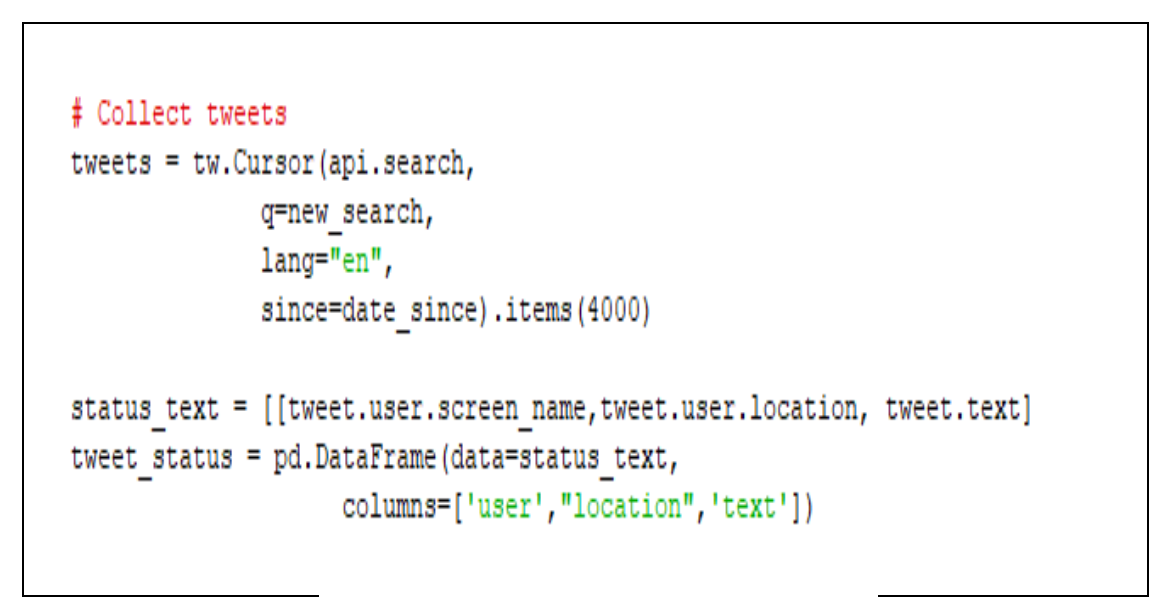

Gambar 2. Python data collection

Pada Gambar 3 ditampilkan contoh 10 baris data collection hasil dari streaming. Data collection hasil streaming data twitter di simpan di database kemudian dilakukan proses data preprocessing dengan cleaning data yang pertama menghapus url pada status tweet.

\begin{tabular}{|c|c|c|c|}
\hline & user & location & text \\
\hline$\theta$ & gocornerblog & Ireland & When you think pubs/clubs will be able to open... \\
\hline & ChorusPhotog & Phoenixville, PA. & Small Town America: Day 41 / 2:20pm / April 28... \\
\hline & AgenciaAJN & Argentina & \#Coronavirus. \#Gaza reopens restaurants for \#R... \\
\hline & crypchart & AMS/RTH & 3 tweets by @WHO that didn't age well. \n\n\#wh... \\
\hline & NPPNewsTV & Pakistan & The \#Coronavirus is Spreading Rapidly Around t... \\
\hline & Asylumseeker $\theta 0$ & & Final update: April 28, 11. 45 PM ISD\n\nTotal.. \\
\hline & sboughorbel & & @MOPHQatar@SidraMedicine @QF @WHO @AJENEWS\n\... \\
\hline & LockdownNo & & This clergyperson says \#lockdown is "loving yo... \\
\hline & rtehrani & Trumbull, & Joseph D’Souza: Coronavirus shows how China's .. \\
\hline & BenSand54338716 & & So the news just told me a 10 year old will ru \\
\hline
\end{tabular}

Gambar 3. Data collection COVID-19

Pada Gambar 4 diperlihatkan contoh data collection status tweet sebelum url di hilangkan. Tweet pada Gambar 4 memiliki beberapa elemen yang tidak di inginkan, URL dan tagar tidak akan dianalisis. Pada penelitian ini untuk menghapus URL (tautan) dan tagar menggunakan ekspresi reguler. Dalam fungsi yang didefinisikan dengan:

re.sub ("([^ 0-9A-Za-z $\backslash \mathbf{t}]) \|(\mid \mathbf{w}+: \backslash / / S+)$ "," ",

Fungsi re.sub digunakan untuk mengganti pilihan karakter yang ditentukan menggunakan ekspresi reguler, untuk menemukan semua string seperti URL dan tagar diganti dengan- "".

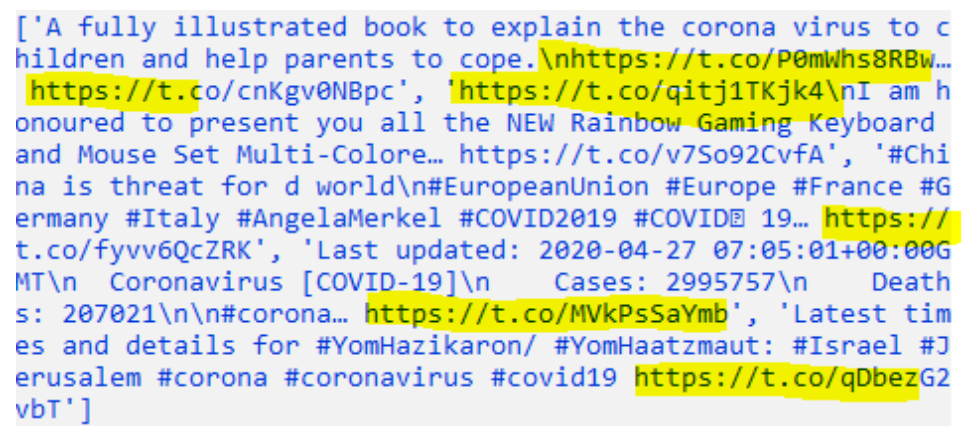

Gambar 4. Tweet preprocessing

Gambar 5 di tampilkan hasil cleaning data hapus url dan tagar. Kapitalisasi kata akan berpengaruh saat analisis text mining. Metode string.lower() digunakan untuk membuat setiap huruf capital menjadi kecil. 


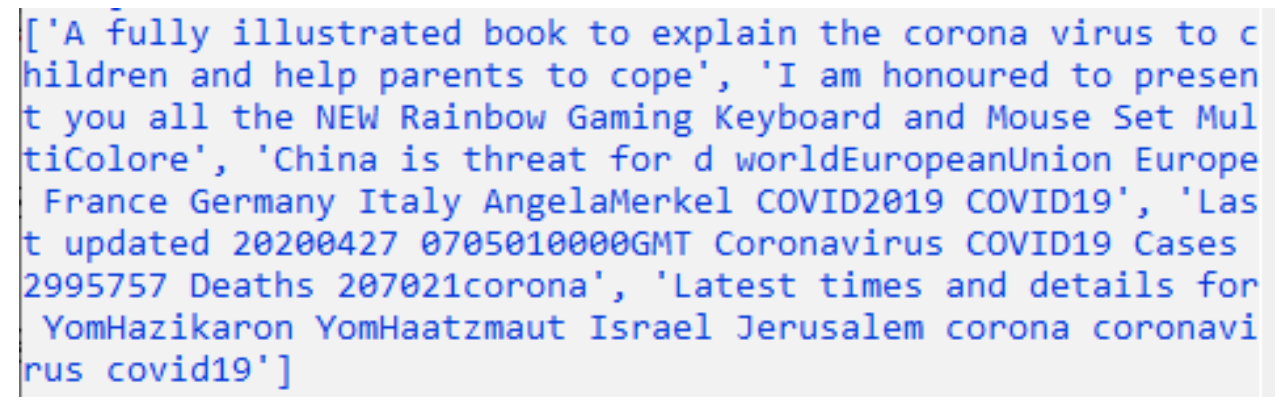

\section{Gambar 5. Tweet cleaning url}

Fungsi set() untuk menampilkan hanya kata-kata unik. Untuk melakukan analisis frekuensi kata, digunakan fungsi split() untuk memisah setiap kata menjadi elemen unik ditampilkan pada Gambar 6.

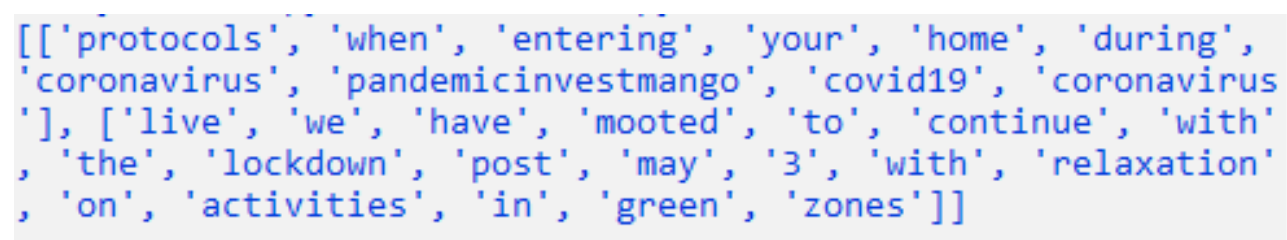

Gambar 6. Tweet cleaning capital

Untuk mendapatkan daftar word frequency berapa kali setiap kata muncul, menggunakan fungsi most_common terdapat pada Objek collection.Counter, yang ditampilkan pada Gambar. 7

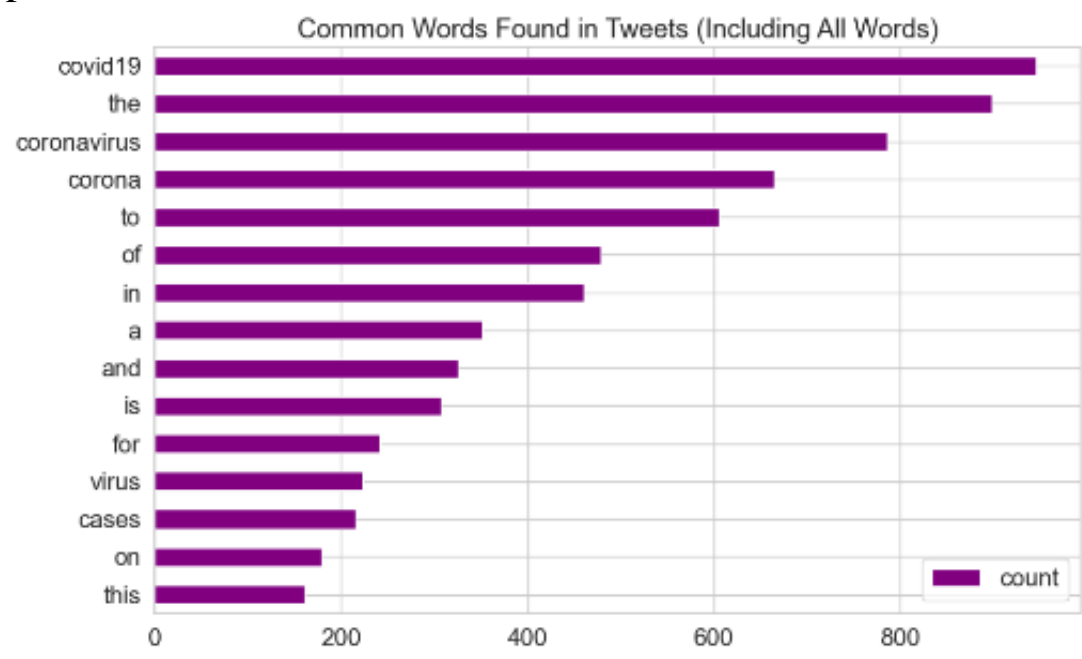

Gambar 7. Tweet word frequency

Bagian yang harus dihilangkan sebelum dilakukan analisis sentiment adalah stopword, kata-kata dengan informasi tidak bermakna untuk analisis text mining. Library Python nltk, menyediakan daftar stopword yang dapat digunakan untuk membersihkan data Twitter. Fungsi nltk hanya dapat bekerja pada semua kata dengan huruf kecil. Pada Gambar 8 di tampilkan word frequency dengan menghapus daftar stopword 


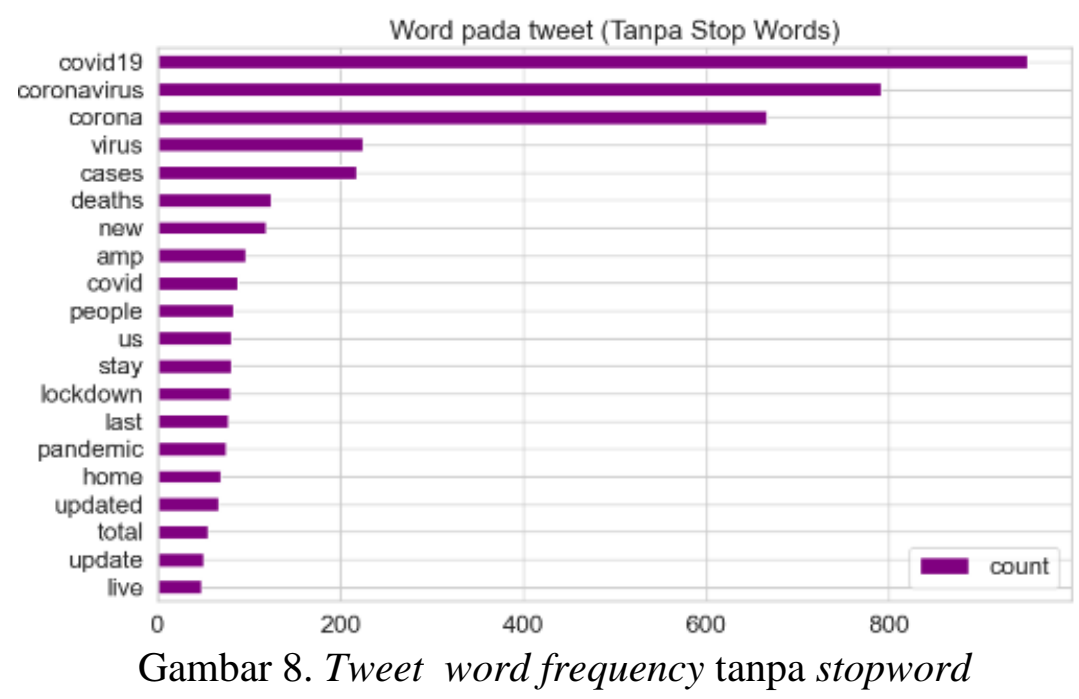

Dengan menghapus collection word data yang di dapatkan dari data cleaning akan menjadi condong ke kata yang akan di analisa, yaitu variable COVID-19 atau coronavirus bahwa istilah ini akan ditemukan di setiap tweet. Pada Gambar 9 ditampilkan 20 daftar kata unik yang telah di proses data cleaning dari penghapusan retweet s, url, tagar, stopword dan data collection

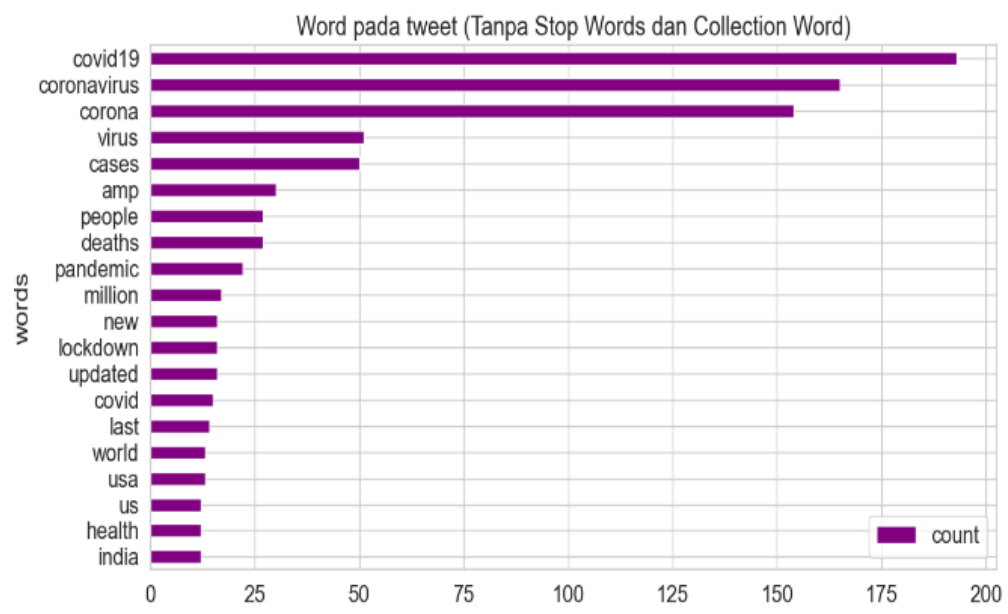

Gambar 9. Tweet data cleaning akhir

Untuk menganalisa hubungan antar kata yang memiliki kemunculan kata bersama di tweet, digunakan fungsi bigrams dari nltk. Daftar bigram kemunculan 20 kata di tweet pada Gambar 10.

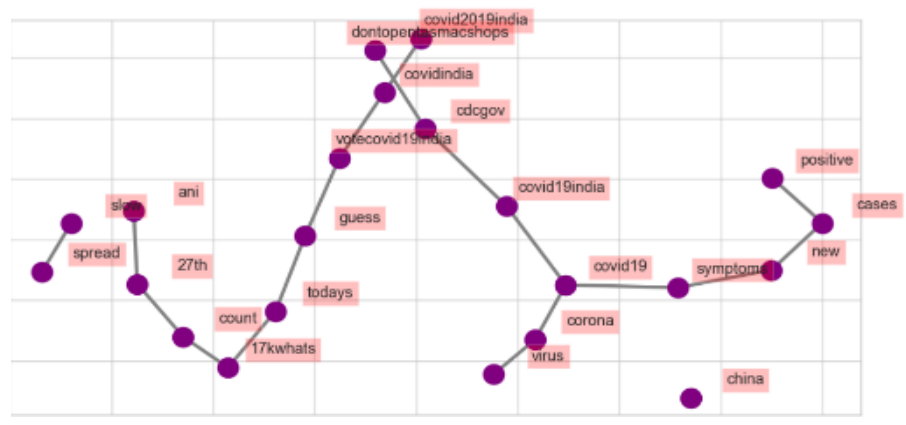

Gambar 10. Tweet bigram 
Hubungan antar kata ditampilkan pada Gambar 11 hasil analisa dengan fungsi ngram dengan CountVectorizer, dimana jumlah kemunculan kata dalam tweet di ubah menjadi matriks vektor.

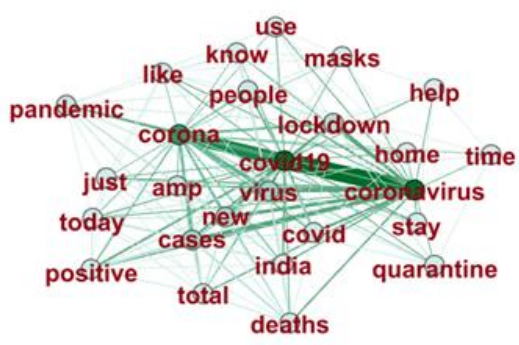

Gambar 11. Tweet ngram

Berdasarkan data yang diperoleh, analisa hubungan antar kata tweet dengan ngram lebih fokus merujuk topik COVID-19 dibandingkan dengan bigram masih muncul daftar kata yang kurang merujuk ke topik COVID-19.

Untuk analisis sentimen dengan fungsi Textblob untuk mengidentifikasi opini kondisi pandemic COVID-19 dari data tweet . Nilai polaritas pada analisa sentiment ini antara 1 sampai -1 . Opini dengan nilai polaritas mengarah ke nilai 1 menunjukkan opini dengan status positif, sedangkan polaritas mengarah ke nilai -1 menunjukkan negative, untuk opini netral nilai polaritas berkisar ke 0. Pada Gambar 12 ditampilkan grafik histogram dari nilai polaritas tweet COVID-19, nilai polaritas tertinggi pada status netral $58,94 \%$ yaitu polaritas status positif sebesar $33,68 \%$ dan negatif $7,36 \%$

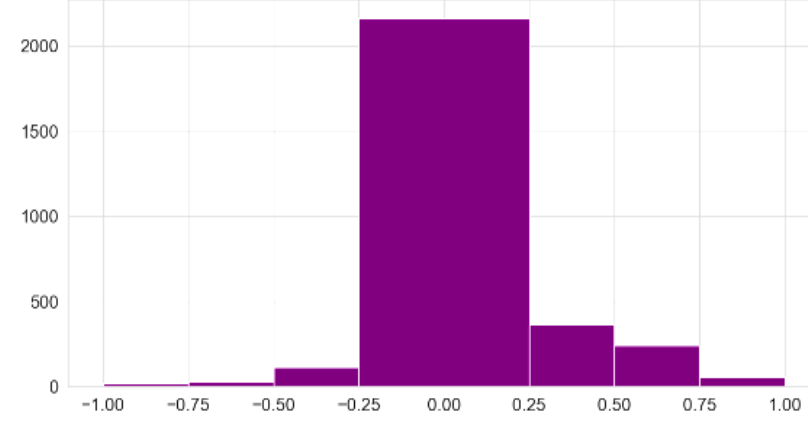

Gambar 12. Analisis sentimen COVID-19

Untuk nilai polaritas dengan variable pencarian coronavirus menunjukan hasil analisa sentimen pada histogram Gambar 13, dengan jumlah nilai polaritas netral 55,10\% positif $24,48 \%$ dan negatif $20,40 \%$. Pada pencarian variable coronavirus lebih tinggi polaritas sentiment negative dari pada pencarian variable COVID-19.

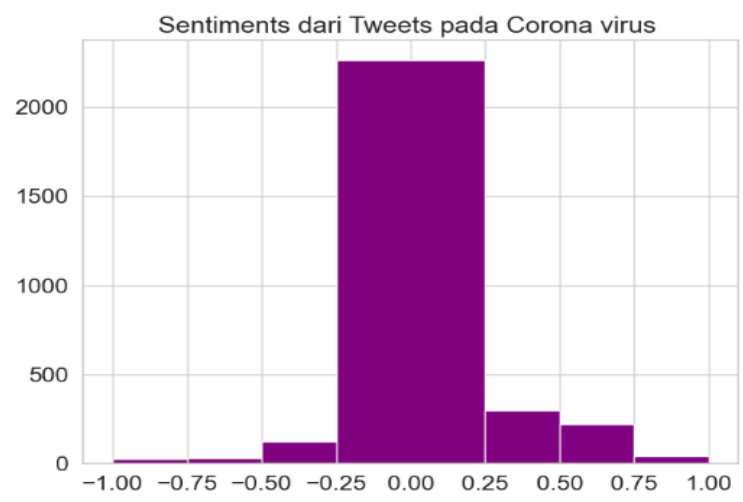

Gambar 13. Analisis sentimen coronavirus 
Pada Gambar 14 ditampilkan beberapa sampel status tweet dengan nilai polaritas tidak sama dengan $0 \quad(!=0)$. Pada Tabel 1 menunjukkan beberapa sampel dari data collection tweet dari analisis sentiment variable \#COVID-19 dan coronavirus dengan kategori positif, netral dan negatif serta nilai polaritasnya. Terdapat nilai polaritas -1 yang mengarah ke opini negatif tetapi terdapat tweet dengan polaritas 1 mengarah ke positif. Berdasarkan hasil analisa sentiment pada tweet yang mengarah pada polaritas negatif terdapat kata-kata yang dikategorikan sebagai opini negatif seperti evil beer virus, terrible, worst, sedangkan pada tweet positif terdapat kata-kata yang dikategorikan sebagai opini positif seperti best.

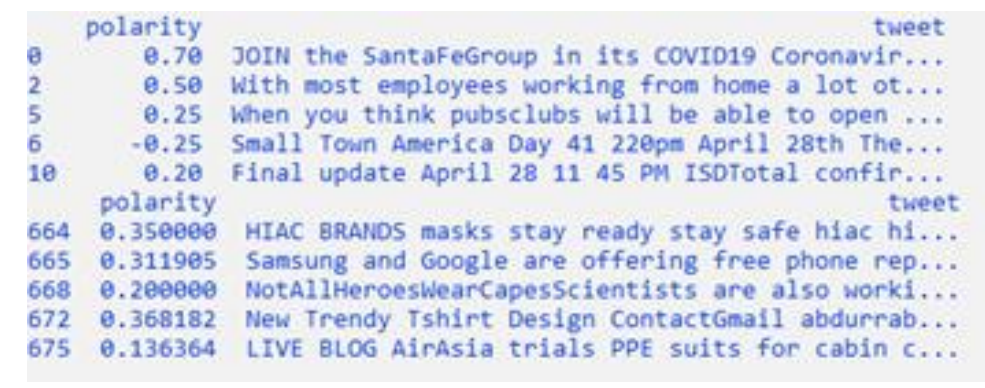

Gambar 14. Tweet polaritas (!=0)

Pada tweet polaritas sentimen netral tidak digunakan penggunaaan kata-kata ungkapan perasaan opini.

Tabel 1. Kategori polaritas tweet

\begin{tabular}{|c|c|c|}
\hline $\begin{array}{c}\text { Nilai } \\
\text { polaritas }\end{array}$ & Tweet & Kategori \\
\hline-1 & $\begin{array}{l}\text { I've got the mask hookup Click the link to protect yourself from the evil beer } \\
\text { virus }\end{array}$ & \multirow[t]{3}{*}{ negatif } \\
\hline-1 & How you get infected with Covid, Corona in your office Terrible & \\
\hline-1 & Worst thing about Corona Introverts are no longer alone at home & \\
\hline 0 & Coronavirus US officially surpasses one million cases coronavirus & \multirow[t]{3}{*}{ netral } \\
\hline 0 & $\begin{array}{l}\text { Kenyas COVID-19 case count increases to } 37414 \text { people dead124 people } \\
\text { recover }\end{array}$ & \\
\hline 0 & $\begin{array}{l}\text { Joseph DSouza Coronavirus shows how Chinas disregard for human rights } \\
\text { threatens the world }\end{array}$ & \\
\hline 1 & $\begin{array}{l}\text { Best coronavirus news in a while scientist UniofOxford speeding ahead in } \\
\text { developing COVID-19 vaccine }\end{array}$ & \multirow[t]{3}{*}{ positif } \\
\hline 1 & $\begin{array}{l}\text { Best facts to understandHighest VE Cases in USAMaximum Death in } \\
\text { USAHighest }\end{array}$ & \\
\hline 0.9 & $\begin{array}{l}\text { Quarantine and Chill with your loved ones Grab the best shows to watch on } \\
\text { the best laptops now }\end{array}$ & \\
\hline
\end{tabular}

Semakin banyak penggunaan kata-kata ekspresi ungkapan perasaan opini baik yang mengarah ke sedih, marah, atau bahagia yang menyebabkan suatu kalimat atau tweet akan memiliki nilai polaritas ke arah negatif atau positif. Sedangkan tweet dengan polaritas sentiment netral memiliki presentase paling tinggi dibandingkan polaritas negative atau positif baik untuk pencarian variable COVID-19 atau coronavirus.

\section{KESIMPULAN DAN SARAN}

\subsection{Kesimpulan}

Pada penelitian ini dilakukan streaming data tweet dengan pencarian data collection dimulai dari 6 April 2020 dan dari hasil analisa sentimen baik pencarian variable COVID19 atau coronavirus, nilai polaritas analisis sentimen kategori netral paling tinggi yaitu 58,94\% untuk sentiment COVID-19 dan 55,10\% untuk variabel coronavirus dibandingkan 
polaritas negatif atau positif. Opini masyarakat pengguna twitter dengan status Bahasa inggris tentang pandemi COVID-19 mulai bulan april 2020 melalui media sosial tweet masih dalam batas netral atau tidak banyak opini negatif yang mengarah ke kondisi kepanikan tetapi juga tidak banyak opini positif masyarakat dalam menghadapi kondisi pandemi COVID-19.

\subsection{Saran}

Pada penelitian ini, analisa sentiment tweet dengan python masih memiliki keterbatasan hanya dilakukan streaming data tweet dengan bahasa inggris, pengembangan selanjutnya dapat dilakukan penelitian analisa sentiment dengan python untuk berbagai bahasa khususnya Indonesia. Data collection tweet yang disimpan masih belum besar dan banyak untuk mengarah ke bigdata.

\section{DAFTAR PUSTAKA}

Adawadkar, K. (2017). Python Programming-Applications and Future. International Journal of Advance Engineering and Research Development, 4(04), 1-4. https://doi.org/10.21090/ijaerd.it032

Cheng, D., Schretlen, P., Kronenfeld, N., Bozowsky, N., \& Wright, W. (2013). Tile based visual analytics for Twitter big data exploratory analysis. Proceedings - 2013 IEEE International Conference on Big Data, Big Data 2013, 2-4. https://doi.org/10.1109/BigData.2013.6691787

Dhawan, Z. (2014). Big Data and Social Media. Research Matters: A Cambridge Assessment Publication, 18, 36-41.

ECDC. (2020). Novel coronavirus disease 2019 ( COVID-19) pandemic: increased transmission in the EU / EEA and the UK - sixth update. Rapid Risk Assessment, 2019(March).

Eroglu, Ç., Allen, N. J., Susman, M. W., Rourke, N. A. O., Young, C., Özkan, E., Chakraborty, C., Mulinyawe, S. B., Annis, D. S., Huberman, A. D., Green, E. M., Lawler, J., Dolmetsch, R., Christopher, K., Smith, S. J., Luo, Z. D., Rosenthal, A., Mosher, D. F., \& Barres, A. (2018). Intelligent Natural Language Processing: Trends and Applications. 740(2), 380-392. https://doi.org/10.1007/978-3-319-67056-0

Kiruthika, S. (2016). Sentiment Analysis of Twitter Data. International Journal of Innovation in Engineering and Technology (IJIET), 6(4).

Luqyana, W. A., Cholissodin, I., \& Perdana, R. S. (2018). Analisis Sentimen Cyberbullying pada Komentar Instagram dengan Metode Klasifikasi Support Vector Machine. 2(11), 4704-4713.

Martin, S., Karafillakis, E., Preet, R., \& Wilder-Smith, A. (2020). The pandemic of social media panic travels faster than the COVID-19 outbreak Dengue Tools View project GBD 2013-2015 Study View project. Article in Journal of Travel Medicine, March. https://doi.org/10.1093/jtm/taaa031/5775501

Yogapreethi, N. (2016). A Review on Text Mining in Data Mining. International Journal on Soft Computing, 7(2/3), 01-08. https://doi.org/10.5121/ijsc.2016.7301

Praneeth Sai, J. V., \& Balachander, B. (2020). Sentimental analysis of twitter data using tweepy and textblob. International Journal of Advanced Science and Technology, 29(3), 6537-6544.

Saini, S. (2019). Sentiment Analysis on Twitter Data using R. 2019 International Conference on Automation, Computational and Technology Management (ICACTM), 68-72.

Setiowati, Y. (2016). Service Extraction and Sentiment Analysis to Indicate Hotel Service Quality in Yogyakarta based on User Opinion. 2018 International Seminar on 
Research of Information Technology and Intelligent Systems (ISRITI), 427-432.

Sivarajah, U., Irani, Z., Gupta, S., \& Mahroof, K. (2019). Role of big data and social media analytics for business to business sustainability: A participatory web context. Industrial Marketing Management, April, 0-1. https://doi.org/10.1016/j.indmarman.2019.04.005

Trupthi, M. (2017). Sentiment analysis on twitter using streaming api. https://doi.org/10.1109/IACC.2017.177 